\title{
KOMPETENSI MAHASISWA TEKNIK MESIN DIPLOMA 3 DAN RELEVANSI DENGAN DUNIA KERJA
}

\author{
Yohanes T. A. Sutrisno ${ }^{1}$, Dedi Rohendi ${ }^{2}$, dan Tatang Permana ${ }^{3}$ \\ Universitas Pendidikan Indonesia \\ Jl. Dr. Setiabudi No. 229 Bandung 40154 \\ yohanestriadisutrisno04@gmail.com
}

\begin{abstract}
ABSTRAK
Penelitian ini bertujuan untuk mengetahui kompetensi mahasiswa dan relevansi dunia kerja lulusan Program Studi Teknik Mesin D3 Konsentrasi Otomotif. Kompetensi yang tertera pada Surat Keterangan Pendamping Ijazah adalah kompetensi mata kuliah dasar teknik mesin dan kompetensi mata kuliah dibidang otomotif yang minimal dimiliki oleh lulusan. Kompetensi ditinjau dari capaian pembelajaran mahasiswa dalam bidang dasar teknik mesin dan bidang otomotif dilihat dari beberapa mata kuliah yang tertera di SKPI. Relevansi dunia kerja yang dimaksud adalah bidang kerja, dan jabatan lulusan di dunia kerja. Relevansi bidang kerja lulusan diukur dari deskripsi pekerjaan, jabatan dan bidang pekerjaan lulusan. Metode yang digunakan dalam penelitian ini adalah metode survei deskriptif analitik dengan pendekatan kuantitatif. Penelitian ini dilakukan pada mahasiswa dan lulusan Program Studi Teknik Mesin D3 Konsentrasi Otomotif. Sampel diambil dengan teknik sampling purposive sebanyak 35 orang. Instrumen penelitian menggunakan kuesioner dan dokumentasi. Hasil penelitian ini diperoleh bahwa kompetensi mahasiswa sudah baik dengan persentase kompetensi mata kuliah dasar teknik mesin sebesar 72,2\% (baik), dan kompetensi mata kuliah bidang otomotif sebesar 82,7\% (baik). Sedangkan relevansi dunia kerja lulusan di peroleh hasil 46\% lulusan yang bekerja, 26\% jabatan lulusan menjadi teknisi, dan relevansi bidang kerja dengan jurusan saat kuliah adalah sebesar 60,9\% sehingga bisa relevan dengan dunia kerja.
\end{abstract}

Kata kunci: kompetensi, mahasiswa, relevansi dunia kerja, teknik mesin.

\section{PENDAHULUAN}

Pendidikan tinggi merupakan salah satu tempat untuk melanjutkan pendidikan dari jenjang pendidikan menengah, diharapkan setelah melanjutkan pendidikan kejenjang yang lebih tinggi bisa meningkatkan kualitas Sumber Daya Manusia (SDM) sehingga bisa mengimbangi perkembangan zaman dan persaingan global tersebut. Pendidikan tinggi mempunyai beberapa jenjang salah satunya yaitu jenjang program diploma, seperti yang tercantum pada Peraturan Pemerintah Nomor 4 Tahun 2014 Pasal 1 Ayat 3 tentang Penyelenggaraan Pendidikan Tinggi dan Pengelolaan Perguruan Tinggi, sebagai berikut: Pendidikan Tinggi adalah jenjang pendidikan setelah pendidikan menengah yang mencakup program diploma, program sarjana, program magister, program doktor, dan program profesi, serta program spesialis, yang diselenggarakan oleh Perguruan Tinggi berdasarkan kebudayaan bangsa Indonesia.

\footnotetext{
${ }^{1}$ Mahasiswa Departemen Pendidikan Teknik Mesin FPTK UPI

2 Dosen Departemen Pendidikan Teknik Mesin FPTK UPI

${ }^{3}$ Dosen Departemen Pendidikan Teknik Mesin FPTK UPI
} 
Program Studi Teknik Mesin D3, Departemen Pendidikan Teknik Mesin (DPTM), Fakultas Pendidikan Teknologi dan Kejuruan (FPTK), Universitas Pendidikan Indonesia sebagai salah satu program studi dari lembaga pendidikan diharapkan dapat menghasilkan lulusan profesional di bidang Teknik Mesin. Lulusannya dapat diserap dunia kerja sesuai dengan kompetensi yang diperolehnya. Lulusan D3 minimal menjadi teknisi/analisis dalam dunia kerja sesuai dengan tingkatan pada KKNI yaitu level 5 (Muslich, 2011).

Standar Kompetensi Lulusan (SKL) merupakan kriteria minimal tentang kualifikasi kemampuan lulusan yang mencangkup sikap, pengetahuan, ketrampilan yang dinyatakan dalam rumusan capaian pembelajaran (Ditjen Dikti, 2014). Program Studi ini menghasilkan lulusan yang memiliki kompetensi ahli madya teknik mesin. Selain itu, prodi ini menghasilkan lulusan yang memiliki kemampuan terapan tentang ilmu dan teknologi dibidang teknik mesin serta memberikan layanan terbaik dan terjangkau bagi masyarakat yang sesuai dengan visi dan misi yang Program Studi Teknik Mesin D3. Lulusan D3 secara umum menurut Capaian Lulusan Program Studi harus mempunyai keterampilan umum lulusan.

Capaian lulusan di atas tentu tidak bisa dicapai dengan maksimal apabila kompetensi dalam perkulihan belum dilaksanakan secara maksimal (Agustin, 2012). Baik oleh pencapaian mahasiswa D3 itu sendiri maupun perangkat pembelajaran dalam perkuliahan. Mahasiswa di pendidikan Teknik Mesin sendiri mempunyai beberapa mata kuliah yang harus dijalani sebagai mahasiswa yaitu: mata kuliah umum, mata kuliah dasar profesi, mata kuliah keahlian profesi, mata kuliah latihan profesi, mata kuliah keahlian, mata kuliah perluasan pendalaman. Mahasiswa D3 Teknik Mesin sendiri wajib mengontrak mata kuliah dengan beban sks berkisar 100-120 sks. Pendataan dan pemetaan lulusan yang bekerja sesuai dengan jurusan saat masa kuliah sangat penting bagi satuan Prodi, khususnya Prodi D3 Teknik Mesin. Oleh karena itu, kompetensi yang diterapkan sesuai dengan borang SKPI di Program Studi D3 Teknik Mesin. Pendataan merupakan bahan acuan untuk mengevaluasi dan mendata seberapa besar capaian kompetensi di perkuliahan, dan relevansi lulusan di dunia kerja yang sesuai dengan jurusan saat berkuliah (Abdurrahman, 2015). Pada kenyataannya pendataan bidang pekerjaan dan jabatan yang sesuai KKNI belum ada pada Prodi D3 Teknik Mesin, sehingga belum adanya data tentang dunia kerja lulusan yang relevan dengan perkuliahan D3 Teknik Mesin. 


\section{METODE PENELITIAN}

Metode yang digunakan adalah penelitian survei deskriptif analitik dengan pendekatan kuantitatif. Penelitian inni merupakan penelitian yang akan mengungkap situasi saat ini terkait dengan topik tertentu. Populasi penelitian ini mahasiswa lulusan Program Studi Teknik Mesin D3 DPTM FPTK UPI konsentrasi otomotif. Sampel penelitian adalah lulusan Program Studi Teknik Mesin D3 Konsentrasi Otomotif jumlah 35 orang. Instrumen penelitian menggunakan kuesioner dan dokumen transkip nilai.

\section{HASIL PENELITIAN}

Hasil penelitian diperoleh nilai dari kompetensi mata kuliah mahasiswa Program Studi Teknik Mesin D3 konsentrasi otomotif yaitu pada bidang mata kuliah keilmuan dasar teknik mesin dan kompetensi mata kuliah keilmuan dibidang otomotif. Perolehan nilai lulusan selama menjadi mahasiswa, diambil dari 7 mata kuliah dasar mesin dan 15 mata kuliah kompetensi bidang otomotif dengan sampel sebanyak 35 lulusan. Persentase kompetensi mahasiswa Teknik Mesin D3 di mata kuliah dasar teknik mesin diketahui sebesar 72,2\% baik, sedangkan 27,8\% belum baik. Kompetensi mahasiswa di bidang otomotif ditinjau dari nilainya adalah sebesar $82,7 \%$ baik, dan $17,3 \%$ belum baik.

Persentase kegiatan lulusan Program Studi Teknik Mesin D3 konsentrasi otomotif DPTM FPTK UPI yaitu sebesar $46 \%$ bekerja, $14 \%$ belum diketahui, $20 \%$ melanjutkan studi ke jenjang Strata 1, $14 \%$ berwirausaha dan $6 \%$ menjadi wiraswasta. Lulusan Program Studi Teknik Mesin D3 konsentrasi otomotif setelah menyelesaikan studi adalah untuk bekerja.

Profesi lulusan Program Studi Teknik Mesin D3 konsentrasi otomotif, yang diinginkan dunia kerja adalah yang relevan dengan jurusan selama kuliah. Persentase profesi lulusan Program Studi Teknik Mesin D3 konsentrasi otomotif diperoleh yaitu 26\% sebagai teknisi, 9\% sebagai basic trainer, 18\% sebagai wirausaha (milik orang tua), 5\% sebagai planing engineer, 4\% sebagai Human Resource Development (HRD), 13\% sebagai guru SMK, 4\% sebagai mekanik, 4\% sebagai foreman, 4\% sebagai Operator, 4\% sebagai CEO, 9\% sebagai Wiraswasta (pedagang). Profesi yang paling diminati oleh lulusan Program Studi Teknik Mesin D3 konsentrasi otomotif adalah teknisi.

Dunia industri yang dimasuki oleh lulusan Program Studi Teknik Mesin D3 konsentrasi otomotif bervariasi. Profesi tersebut antara lain: bidang teknik mesin/otomotif, wirausaha (selain otomotif), elektronik, dan sipil/kontruksi. Relevansi dibidang teknik mesin/otomotif atau yang relevan dengan teknik mesin/otomotif sebesar 60,9\%. Tidak relevan dengan bidang teknik mesin/otomotif sebesar $39,1 \%$. 


\section{PEMBAHASAN}

Kompetensi mata kuliah dasar teknik mesin sebesar $72,2 \%$ baik dan $27,8 \%$ belum baik. Kompetensi mata kuliah bidang otomotif sebesar $82,7 \%$ baik dan 17, 3\% belum baik. Kompetensi merupakan pernyataan kemampuan yang menguraikan hasil yang diharapkan dari profesi yang terkait, atau pengetahuan, keterampilan, dan sikap, yang penting dalam pekerjaan tertentu (Jatmoko, 2013). Salah satu ukuran pencapaian kompetensi pada mahasiswa D3 adalah dengan nilai yang diperoleh selama masa perkuliahan. Capaian kompetensi dikelompokan menjadi 2 capaian kompetensi yaitu baik dan belum baik. Kategori baik dengan di atas nilai B-, dan kategori belum baik dengan nilai C+ ke bawah. Telah diperoleh data nilai sesuai dengan patokan penilaian Universitas Pendidikan Indonesia. Nilai mahasiswa D3 Teknik Mesin Konsentrasi Otomotif masuk kategori baik diukur dari capaian nilai (Sanjaya, 2011). Perolehan nilai tersebut sudah melampaui batas minimal pencapaian kelulusan dan dianggap menguasai kompetensi mata kuliah.

Lulusan Program Studi Teknik Mesin D3 konsentrasi otomotif sebanyak 41\% bekerja, $18 \%$ melanjutkan studi, dan $13 \%$ berwirausaha. Kondisi ini sesuai dengan visi, misi dan tujuan dari Program Studi Teknik Mesin D3. Hasil tersebut sesuai dengan tujuan pendidikan vokasi. Pendidikan vokasi merupakan pendidikan tinggi yang mempersiapkan peserta belajar untuk memiliki pekerjaan dengan keahlian terapan tertentu maksimal setara dengan program sarjana (Kuswana, 2013).

Posisi/jabatan dalam dunia kerja yang paling dominan adalah sebagai teknisi yaitu 26\%. Nilai ini cukup besar dan sesuai dengan kualifikasi KKNI yang dijelaskan pada Peraturan Presiden Republik Indonesia Nomor 8 Tahun 2012 tentang KKNI, posisi pada jenjang kualifikasi KKNI untuk lulusan D3 maka ketika memasuki dunia kerja posisinya pada level 5 yaitu sebagai teknisi.

Menurut pengelompokan bidang kerja diperoleh bidang kerja yang relevan dengan jurusan Teknik Mesin adalah sebanyak 14 orang dari jumlah 23 orang yang bekerja atau relevansinya sebesar 60,9\%. Data sebesar 60,9\% lulusan bekerja sesuai dengan program studinya, dapat di katakan relevan dengan dunia industri. Implikasi yang ditimbulkan yaitu dengan meningkatkan kemampuan dan mengevalusi kompetensi yang relevan bagi lulusan (Muhson, 2012). Data kompetensi menunjukkan baik, tetapi masih beberapa mata kuliah dasar teknik mesin yang dianggap masih lemah karena nilai yang diperoleh belum secara maksimal. Kompetansi mata kuliah dibidang otomotif sudah bagus karena perolehan nilai yang cukup tinggi. Relevansi dunia kerja yang dimiliki oleh lulusan memberikan rasa percaya diri kepada angkatan berikutnya untuk memasuki dunia industri (Mariana, 2015). 
Terbuka jaringan dan akses dengan berbagai dunia kerja yang nantinya bisa tindaklanjuti untuk dijadikan relasi dan kerjasama dalam perekrutan.

\section{KESIMPULAN}

Kesimpulan sebagai berikut: kompetensi yang dicapai sudah baik dilihat dari nilai dan persentase yang diperoleh mahasiswa. Nilai tersebut sudah melebihi standar minimum kelulusan mata kuliah untuk D3. Relevansi lulusan Program Studi Teknik Mesin D3 dengan dunia kerja sudah baik. Profesi teknisi merupakan pilihan yang paling banya diminati oleh luulusan. Lulusan sudah memenuhi dan sesuai dengan standar kerja menurut KKNI yaitu pada level 5. Relevansi antara dunia kerja dengan lulusan sudah baik dan lulusan diterima bekerja sesuai dengan prodi Teknik Mesin D3 dengan persentase relevansi sebesar 60,9\%.

\section{REFERENSI}

Abdurrahman. (2015). Upaya Mengurangi Kelelahan dalam Kompetensi Keahlian Otomotif di Sekolah Menengah Kejuruan dengan Uji Model Tidak Kontinyu. Jurnal Pendidikan dan Kebudayaan, 21(1) hlm. 53-69.

Agustin, V. (2012). Kompetensi Lulusan Sarjana Strata 1 (S1) Psikologi dalam Menghadapi Dunia Kerja pada Mahasiswa Perguruan Tinggi "X". Jurnal Ilmiah Mahasiswa Universitas Surabaya. 1(1).

Ditjen Dikti. (2014). Panduan Penyusunan Capaian Pembelajaraan Lulusan Program Studi. Jakarta: Direktorat Pembelajaran dan Kemahasiswaan.

Jatmoko, D. (2013). Relevansi Kurikulum SMK Kompetensi Keahlian Teknik Kendaraan Ringan terhadap Kebutuhan Dunia Industri di Kabupaten Sleman. Jurnal Pendidikan Vokasi, 3(1) hlm. 1-13.

Kuswana, W, S. (2013). Dasar-Dasar Pendidikan Vokasi \& Kejuruan. Bandung: Alfabeta.

Mariana, N. (2015). Tracer Studi Mahasiswa Program Studi Sistem Informasi Universitas STIKUBANK Semarang. Jurnal Dinamika Informatika. 7(2) hlm. 73-84.

Muslich, M. (2011). KTSP Pembelajaran Berbasis Kompetensi dan Kontekstual. Jakarta: Bumi Aksara.

Muhson, A. (2012). Analisis Relevansi Lulusan Perguruan Tinggi dengan Dunia Kerja. Jurnal Economia, 8(1) hlm. 42-52.

Sanjaya, W. (2011). Pembelajaran dalam Implementasi Kurikulum Berbasis Kompetensi. Jakarta: Kencana. 